\title{
Research on the Teaching Reform in Computer Basic Course Centered on Improving Information Literacy*
}

\author{
HUANG Pei-hua \\ Binzhou University, Shandong, China
}

\begin{abstract}
In the current modern society, information technology enjoys rapid development and information resources increase sharply. In this context, information literacy has been an important indicator for assessing a talent's comprehensive quality. As a compulsory public course for college students not majoring in computers, computer basic course plays a significant role in cultivating college students' information literacy. However, how to improve contemporary college students' information literacy, facilitate the teaching reform in fundamental computer education, and effectively improve college students' capacities of solving problems with computers is a difficult question faced by fundamental computer education in colleges and universities.
\end{abstract}

Keywords: information literacy, computer basic course, talent cultivation

\section{Introduction}

In the current information society, the demands for talent cultivation keep changing. As the reform in higher education deepens, the fundamental computer education of colleges and universities enjoys rapid development. Nowadays, the computer basic course of universities has been an important link of Chinese computer education system. It plays a crucial role in imparting computer-related knowledge to students not majoring in computer and developing their application capacities. In addition, it significantly facilitates the application and development of Chinese national information technology. In this context, enhancing the education in computer and information technology is an important component of cultivating all-rounded talents with high qualities, innovation capacities, and an entrepreneurship spirit. For this reason, improving college students' information literacy plays a crucial role in facilitating all-rounded information construction.

\section{Status Analysis of Basic Computer Course Teaching}

The teaching of basic computer course aims to cultivate students' capacities of solving problems in professional domains and daily affairs with computer-related knowledge and high information literacy of communicating and expressing with computers, as well as learning on the Internet.

At present, domestic and foreign universities provide fundamental public courses on computers to students not majoring in computer and teach them common and basic knowledge on computers. In the beginning, the fundamental computer education aimed to impart basic knowledge on computers to students, cultivate their basic skills, and develop professional capacities of operating on computers and programming. As the era

\footnotetext{
* Acknowledgements: This research was financially supported by the Research on teaching reform project of Binzhou University (No.BYJYYB201524) and Shandong Education Science 12th Five-Year plan topic (No.YB15002).

HUANG Pei-hua, lecturer, M.A., Department of Information and Engineering, Binzhou University, Shandong, China.
} 
advances, however, it puts forward increasingly high requirements on college students' computer application capacities: Apart from being capable of using computers skillfully, students should develop necessary skills and capacities of solving problems with computer technology (DAI \& WANG, 2011). It is thus necessary to improve students' all-rounded information literacy and enable students to meet the demands for fast development in the information era, thereby laying a solid foundation for solving problems in future work.

\section{Basic Concept of Information Literacy}

The concept of information literacy originated from book retrieval skill. The term was first put forward by Paul Zurokwski, chairman of American Information Industry Association in 1974. Paul defined it as the technology and skill of solving problems. As information technology enjoys constant development, the definition of information literacy also expands and ushers in more connotations. Ever since its occurrence, scholars at home and abroad have enriched and expanded the connotations of information literacy and associated it with critical thinking and problem-solving capacity, which lay the foundation for teaching students how to learn and how to innovate in knowledge (Kong, 2014). American Library Association (ALA) defined information literacy as: Information literacy is the capacities of judging when information is needed, retrieving information, evaluating information, and effectively using information. According to ALA, information literacy includes information consciousness, information knowledge, information competence, and information morality (Thornton \& Kaya, 2013).

Compared with foreign education, domestic education in college students' information literacy enjoyed a late start and did not become popular until recent years. For college students, information competence and information literacy improve as the grade increases. However, students' overall capacities are not optimistic, which is represented in weak awareness of obtaining information, low initiative and enthusiasm for information needs, and poor information competence. Although most students are capable of using computers, they lack the skills of retrieving information, the knowledge on processing information and accumulating knowledge through computers.

\section{Teaching Reform in Computer Basic Course Based on Improving Information Literacy}

In an information society, no one can live without information. To some extent, an individual's capacity of obtaining information, processing information, and using information will affect his future work and life. It can be said that information literacy is the basic quality for everyone living in the information era.

\section{Requirements on Cultivating Information Literacy}

In general, information literacy should be improved from four aspects.

Cultivate and improve information literacy. As an important component of information literacy, information security literacy is one of the basic capacities for adapting to diverse information conditions. In addition, cultivating students' good information security literacy is the foundation of setting up a guarantee system for information security (Uchmo \& Watanahe, 2015).

Information security literacy focuses on the thinking and literacy of information and Internet security. Its core lies in knowing the basic principles of how computer virus and online attacks undermine computer and Internet security and how to prevent them. It eventually aims to enhance the capacity of safeguarding information and Internet security. 
Information layout and publishing literacy. Information layout and publishing literacy refers to how to arrange and publish works and achievements. It pays attention to understanding the component elements and publishing requirements of different publications, including books, magazines, electronic speech drafts, and e-media. Its essence lies in learning the methods and skills of organizing learning contents, rather than diverse text processing software. Whether one is capable of using text processing software is a question and whether one can arrange publications that meet requirements and have exquisite formats with text processing software is another. The former requires learning and mastering software, while the later focuses on cultivating literaryinformation publication literacy.

Literacy of information data processing. The literacy of information data processing refers to how to manage and use data. It pays attention to students' thinking and literacy related to data. Its core is database and the problem of using data based on databases. The literary aims to teach students to understand the importance and methodology of data management, use data processing approaches based on databases, and understand the social impact of database (ZHANG, 2013).

Information internet literacy. Information Internet literacy refers to how to connect and use the Internet. It pays attention to the thinking and literacy related to Internet. In addition, its core lies in the methodology of connecting the Internet and the problems in using the Internet. It aims to teach students core concepts about machine- Internet connection and information transmission, so as to understand how to apply information network and social network as well as how the Internet affects individuals and society.

\section{Teaching Reform}

Nowadays, information technology is changing fast, making it necessary for teachers to update teaching contents in time. As the era advances, students should not only master essential information technology, knowledge, and skills needed by social life, but more importantly develop excellent information literacy and relevant capacities. This is because information literacy and competence are cores of development in an information society. At present, the knowledge and application skill emphasized by basic computer course should be elevated to information capacities and literacy to re-understand a series of problems, including the status, role, and significance of this course, its teaching objectives, and evaluation system.

Innovate in teaching methodology \& concepts and cultivate information consciousness. The basic computer course is highly practical. However, traditional teaching models lack research and are unfavorable for students to understand, use, and innovate in knowledge and skills. It is thus necessary to set up learning objectives or tasks and divide students into different groups or teams to improve their learning efficiency. In addition, the application of multi-media teaching technology and equipment facilitates information sharing, negotiations and discussions, cooperation and communications. Nowadays, teachers' functions and roles have changed substantially. Teachers should provide students with learning resources, necessary guidance, and services through new media technology. In addition, teachers should enlighten and cultivate students' information consciousness. This is because information consciousness allows students to focus on and collect necessary information in future study and work, as well as gradually develop good habits of using information.

Conduct task-driven teaching through new media technology and cultivate students' information application capacities. College students' information literacy level depends on their familiarity with information technology. Nowadays, the infusion teaching of traditional teaching models is ineffective. If students do not understand knowledge thoroughly and do not know how to apply it, they may lose interest in 
computers. For this reason, task-driven teaching provides students with a more ideal learning environment, inspires students' interest, and improves the teaching quality in class.

Teachers should conduct task-driven teaching in three links, including task planning, task implementation, and task evaluation. In the phase of designing planning, teachers should combine teaching contents and students' status and follow the principle of progressive education. In the phase of task implementation, teachers should analyze tasks first, collect effective information, and find out solutions to problems. In the phase of task evaluation, all evaluations should be comprehensive, in time, and objective. Apart from mutual evaluations between students and teachers, teachers should have self-reflections. Lastly, teachers should guide students effectively and cultivate students' capacities of information application. This helps students to master and apply knowledge on computers better.

Encourage independent learning and cultivate information innovation capacity. Students should have independent learning under teachers' guidance. This is crucial because students' capacities of discovering problems, retrieving, collecting information, and having communications and explorations help them to master knowledge and improve skills. More importantly, such capacities facilitate the healthy development of students' emotions, attitudes, and particularly exploration spirit and innovation capacity. First of all, teachers should provide correct ideological education, teach students the correct significance of study, and inspire their enthusiasm for participating in innovation. Secondly, teachers may provide correct independent learning methods, create a good learning atmosphere, and inspire students' curiosity for knowledge, so as to improve students' innovative thinking and capacities. Last but not least, teachers should pay attention to cultivating students' divergent and convergent thinking. In this way, students are able to make comparisons and conclusions to seek solutions and improve their innovation capacities.

The teaching models of basic computer course, which base on cultivating college students' information literacy, should meet the basic laws of teaching and follow the principle of progressive education. Most importantly, teachers should be student-oriented in teaching, focus on improving students' overall qualities, and facilitate their comprehensive, all-rounded, and individual development. Only in this way can students have qualities and capacities needed by the future.

\section{Conclusion}

In conclusion, information literacy education is a major project of education reform and development. It plays an important role in cultivating students' information literacy, information skills, and information innovations. More importantly, it aims at cultivating talents with practical capacities and innovation spirit, ensuring students' diversified development, and enhancing students' intelligence.

Improving college students' information literacy is the requirement placed by information era on cultivating higher education talents and the precondition of lifelong learning. At present, the college basic computer course is the primary means of cultivating and improving contemporary college students' information literacy that meets the needs of modern information society. In essence, information literacy is an information-based capacity. The basic computer course aims at cultivating college students' strong information consciousness, improving college students' information capacity, and enhancing their sensitivity towards information, observation capacity, and analytical capacity. It is thus of great significance for improving college students' comprehensive qualities. 


\section{References}

DAI, X. H., \& WANG, G. L. (2011). Research on and practice of teaching reform in the basic computer course of college students not majored in computers. Journal of Chongqing Technology and Business University, 28(3), 322-326.

Kong, S. C. (2014). Developing information literacy and critical thinking skills through domain knowledge learning in digital class-rooms: An experience of practicing flipped classroom strategy. Computer \& Education, 78(9), 16-173.

Thornton, D. E., \& Kaya, E. (2013). All the worldwide web's a stage: Improving students' information skills with dramatic video tutorials. Aslib Proceedings, 65(1).

Uchmo, K., Okubo, Y., \& Watanahe, T. (2015). Approach to education innovation making use of open content. Fujitsu Scientific \& Technical Journal, 51(1), 70-76.

ZHANG, G. R. (2013). New thought on reforming the fundamentals of computer based on flipped classroom. University Education, 7, 135-137. 